\title{
Study on the Imbalance Reasons and the Equilibrium Strategy of Information Resources of Basic Education in Urban and Rural Areas
}

\author{
Huimin Fan \\ School of Educational Science \\ Heihe University \\ Heihe, China
}

\author{
Lirong Song \\ School of Educational Science \\ Heihe University \\ Heihe, China
}

\begin{abstract}
Basic education informatization is an important part of education informationization, and it is the inevitable requirement of the development of social information. With the improvement of economic development level and the popularization of compulsory education, basic education conditions and teaching quality have obvious improvement. As the second largest city in Heilongjiang Province, Qigihar City pushes the basic education information hard, and requires the basic education information to achieve a healthy and orderly development to achieve balanced configuration of education information resources.
\end{abstract}

Keywords - basic education informationization; educational equity; resource balanced allocation

\section{INTRODUCTION}

At this stage, the basic education information network facilities and other infrastructure has been basically completed. However, the balanced configurations of educational information development lack overall planning and design, and there still exists distinction in different regions.

\section{AN OVERVIEW OF RESOURCES ALLOCATION OF BASIC} EDUCATION INFORMATION IN URBAN AND RURAL AREAS

\section{A. Basic Education}

Basic education is the knowledge that people need to master in order to gain more knowledge in the process of growing. Just like building the foundation of a house, in order to learn a foreign language well, we must know how to read from the beginning. Basic education, as a foundation for training talents and improving the quality of the nation, has played an important role in the education reform in twentyfirst Century. According to "the general situation of basic education development in China", "basic education in our country includes early childhood education, primary education, secondary education."

Fund program: the thesis serves for Heilongjiang Province philosophy and social science research plan annual project "Research on resources. equilibrium allocation of basic education in urban and rural areas in Heilongjiang Province (project number: 15EDE08)

\section{B. Educational Information}

Education informatization, in other words, refers to the process of using modern information technology, developing educational resources, optimizing the process of education to cultivate and improve the information literacy of students, and promote the modernization of education." [1] "education informationization refers to all aspects in the field of education and teaching. Under the guidance of advanced education, applying information technology positively, developing in-depth, using information resources widely to cultivate innovative talents meeting the requirement of information society and speed up the realization of the systems engineering of education modernization." [2]

\section{Balanced Allocation of Resources}

Resources allocation refers to the distribution that some resources between different uses, among different regions and departments are allocated, the allocation of educational resources is a kind of distribution among education system internal components or different sub systems. It not only includes the distribution of the total resources of the society to the education, but also the distribution of the educational resources at various levels of education, schools, and educational resources among different regions.

This thesis aims to improve the information literacy into the educational objectives, train talents to adapt to the information society, and apply the information technology to teaching and scientific research, in the meanwhile, focus on the development and use of educational information resources.

III. THE ANALYSIS OF RESOURCES ALLOCATION IMBALANCE REASON OF BASIC EDUCATION INFORMATION IN URBAN AND RURAL AREAS

\section{A. Infrastructure Faultiness of Rural Basic Education Information Resources and Facilities}

The main performance of imbalanced urban and rural school information teaching resources equipment is 
unbalanced teaching resources. There is a big problem in the construction of basic education information resources in rural areas.

1) Unreasonable Educational Information Resources and Facilities Allocation: Although both the rural and urban areas purchased teaching resources through the higher authorities, however, the purchase of the two is different, city schools are far more than the rural schools. In addition, the emphasis of the higher authorities on schools' infrastructure construction directly affects the development of the whole school. Urban schools are the focus of the majority of educational funds, and the phenomenon still exists that rural education funds cannot be in place timely, which lead to the impracticability of the multimedia teaching.

2) Uneven Distribution of Campus Network: The coverage of city campus network is 2 times that of the rural areas, the uneven distribution of rural campus network is not conducive to the exchanges of high-quality educational resources and sharing between urban and rural schools. It also is not conducive to the teachers to enrich their knowledge through the network, while the construction of campus network in urban schools provide different schools with convenient conditions for sharing teaching resources making urban schools develop more rapidly. However, the lag of rural schools contributed greatly to the effect of urban and rural education.

\section{B. Rural Laggard Understanding of the Development of Basic Education Informatization}

Because the local government, school leaders and the rural schools' misunderstanding of the basic education information, they think that information is only a kind of display even feeling that it is set up only in order to deal with the inspection. In this case, on the one hand, it will lead to that the school teachers cannot accept good education information technology training, not conducive to teachers' reform and innovation in the curriculum. On the other hand, the indifference of higher authorities directly affect the school's running conditions, as time passes, outdated equipment, equipment aging and other issues appear, which is not conducive to the overall development of the school.

Teachers' indifference to the teaching of information will affect the results of students' learning directly, it is unfair for the students in rural schools who have the rights to enjoy a fair study. Under the background of the modern information age, teachers have the responsibility and obligation to cultivate students' all-round development in various aspects. Between urban and rural schools, the upper leadership's misunderstanding of the information concept leads to the existence of unbalanced management between urban and rural schools. Urban schools are more professional and innovative ability is stronger compared to rural schools. And the slight phenomenon of rural schools are very common. Therefore, in terms of teacher training and teacher welfare, there exist great differences, urban and rural school teachers cannot enjoy the same rights. Without rural teachers' high professional identity, it intensifies the flow of urban and rural teachers in a certain degree.

At the same time, the differences in thinking and understanding to education informatization in urban and rural areas result in low availability of information resource between urban and rural schools, also result in the waste of information resources. Only reasonable planning and scientific management between urban and rural schools exists will the resources get more attention.

\section{Local Financial Sector'S Imbalanced Investment of Educational Fund on the Urban and Rural Education}

In terms of economic investment, there is a big gap in the regional economic development speed and level, schools largely depend on the economic development level of the entire region. The level of economic development affects the investment on basic education informatization of local government directly, and the backward economic development results in the fund investment insufficiency on education in rural areas for quite a long time, which affects the development of rural basic education informatization directly. In contrast, urban schools are more likely to raise funds for the development of basic education information, and rural schools under the influence of economic and other constraints, the funds of basic education information development cannot be guaranteed.

The fund investment on education of financial sector between urban and rural school still focuses on the city schools. They pay more attention to the construction of information resources in city schools, and the practices cause the gap between city schools and rural schools bigger and bigger. Besides, rural schools have always been in the condition of deficient infrastructure and hardware construction, and teachers in rural schools cannot contact more information resources to expand their knowledge of information technology. Even if the relevant departments or schools carry out relevant training courses regularly, there is no way to apply their knowledge leading to the big problems in the information resources between city and rural schools, and also increased the gap between them.

\section{DIFFERENCES IN THE INFORMATION TECHNOLOGY LEVELS BETWEEN URBAN AND RURAL TEACHERS}

As the main implement of education informatization, teachers' information technology will affect the overall situation of the whole education teaching directly. From the aspect of teachers using electronic equipment to prepare for teaching, the big gap can be seen between urban school teachers and rural school teachers. Comparatively speaking, the lack of rural teachers' information ability and the problem of low professional quality highlights. In addition to this, most of the rural teachers use information resources not positively, which will not only leads to the reduction of availability of digital resources in the process of teaching, it will also affect the rural school students' unequal acceptance of knowledge in the process of obtaining the network learning. According to the previous data, we can see that in the aspect of teachers using electronic equipment to prepare 
for teaching, the technical level of rural teachers are far less than urban teachers in the level of office software understanding, and differences exist between rural teachers' proficiency and urban teachers. At the same time, in related technical problems, city teachers' professional skills are higher than teachers in rural areas.

\section{BALANCED ALLOCATION STRATEGY OF URBAN AND RURAL BASIC EDUCATION INFORMATIZATION RESOURCES}

\section{A. strengthening the construction of teaching staff}

1) enhancing the training of rural teachers in order to improve the level of information technology in rural schools

Strengthening the training of rural teachers should be carried out from two aspects of the ideology and information technology. Main measures are:

- the relevant departments organize persons in charge of each school to hold the training of social informatization and basic education informatization to let the persons in charge realize the importance of basic education informatization from deep thoughts. After improving their thoughts, unified training should be organized;

- school holds school-based training for teachers. It refers to the school as a unit, aiming at improving the level of teachers and teaching ability, as an important form of continuing education for teachers, it is conducive to maintaining teaching order in school.

2) Establishing the Interactive Mechanism between Urban and Rural Teachers to Promote Teachers Progressing in the Interaction

The exchange of information is helpful for teachers to improve their professional and technical level in the field of education and teaching. Therefore, it is feasible to establish an interactive mechanism between urban and rural teachers. On the one hand, rural and urban schools can organize the activities themselves by way of selecting some excellent teachers from urban schools to rural schools to share their experiences, in the meanwhile, selecting flexible teachers from the rural schools to urban schools to learn and accumulate teaching experience and information technology. On the other hand, the urban schools and rural schools can also use the network platform for exchange information to let teachers exchange experience through the network. This can not only improve the usage rate of teachers in the application of information technology, but also enhance teachers' ability of digital resources.

In this way, teachers in rural areas can improve themselves through communication with urban teachers in teaching, whether in the field of mastering information technology, or in the field of education and teaching. It allows the rural teachers learn ways and methods of teaching information from classroom learning, meanwhile, city teachers will have the empathy. Under the background of the rural environment, how to improve personal information teaching quality through their own information technology to create a sound urban and rural teachers interaction mechanism, which is conducive to the improvement of the overall technological level of rural teachers, narrow the urban and rural teachers differences in the implementation of the information technology, and promote the rational allocation of urban and rural teachers. It is helpful to the balanced development of urban and rural education information.

\section{B. Increasing the Government's Investment in Rural Basic Education Information}

The main reason for the urban and rural basic education information is how much money is invested. To have a balanced development of urban schools and rural schools in the basic education informatization, we must increase the investment in rural basic education information technology to reduce the gap between urban schools and rural schools. The construction of basic education information needs a large amount of funds investment, while in the less developed areas- rural areas, the economic level is relatively low.

To make the informationization of basic education in rural schools catching up with the urban school informatization level, and strengthen rural basic education informationization development, governments at all levels and relevant departments must increase funding for rural schools of the informatization of basic education to ensure that there are more outstanding education equipment, teachers, and educational resources sending to rural areas. To achieve the goal that students living in rural schools can enjoy the fair use of digital resources.

When the government increases funds investment in basic education information, they also should encourage the rural schools to obtain education funds through a variety of channels. In this way can the situation of insufficient facilities in school be improved.

\section{Speeding up the Construction of Educational Information and Promote the Sharing of High-quality Education Resources}

Information is a very important part of education information. Education resources network, education information technology resources sharing and so on in the society play an important role in social benefits. The distance education information at home and abroad and in the province is by means of the best quality of educational resources to achieve the goal of improving teachers teaching levels, teaching objectives, teaching quality. Thus it narrows the development gap between regions, and fully shows the development platform of regional basic education as well.

The problem of funding is an important issue in the construction of information technology in schools. For the questions, the following suggestions are provided: first, in the construction of the teachers to do the job well, improve teachers' qualities, and keep pace with the times. Preparatory study of modern information technology, scientific and cultural knowledge to improve the modernization; second, raising funds from various angles, and establish some columns related to the computer network gradually relying 
on the middle schools and primary schools in rural towns. Because it can not only serve for the school's educational information, but also for the municipal government and offer good service to farmers to narrow down the regional gap quickly.

\section{REFERENCES}

[1] Wang Daguang, $\mathrm{Hu}$ Huajin, sun Qingai. The Survey and Development Strategies of Guangxi University Educational Informationalization [J]. Higher Education Forum, 2015, (05).

[2] Yu Xueyong. The Analysis of Multi-Perspective of Educational Information $[\mathrm{J}]$. Journal of Chifeng University (Natural Science Edition), 2013, (09).

[3] Xiong Caiping, Wu Ruihua. Balanced Development of Basic Education in Urban and Rural Areas: Problems and Countermeasures-An Empirical Study of Taizhou City, Zhejiang province [J]. Educational Research, 2006, (3). 